\title{
Pemanfaatan Vesica Urinaria Babi sebagai Extracellular Matriks terhadap Proses Penyembuhan Luka Terbuka pada Tikus Putih
}

\section{(UTILIZATION OF VESICA URINARIA BABI AS AN EXTRACELLULAR MATRIX FOR THE HEALING PROCESS OF OPEN WOUNDS IN WHITE MICE)}

\author{
Wayan Herry Gumawan ${ }^{1 *}$, Wayan Wirata ${ }^{1}$, Wayan Gorda ${ }^{1}$, Luh Made Sudimartini ${ }^{2}$ \\ ${ }^{1}$ Laboratorium Bedah dan Radiologi Veteriner, ${ }^{2}$ Laboratorium Farmasi Veteriner, Fakultas \\ Kedokteran Hewan; Universitas Udayana. Jl. PB. Sudirman, Denpasar, Bali. \\ *Email: herrygumawan06@gmail.com
}

\begin{abstract}
ABSTRAK
Extracellular matrix (ECM) saat ini adalah salah satu yang paling umum digunakan sebagai perancah untuk prosedur rekayasa jaringan. Extracellular matrix (ECM) bisa berasal dari submukosa usus kecil atau vesica urinaria (kandung kemih) babi. Tujuan penelitian ini adalah untuk mengetahui tingkat kecocokan dan keamanan penggunaan vesica urinaria babi sebagai Extracellular matrix (ECM) terhadap proses kesembuhan luka terbuka pada tikus putih serta mengetahui perubahan yang terjadi pada daerah implan pasca pemberian bahan serbuk vesica urinaria yang diamati secara makroskopis. Tiga puluh dua ekor tikus putih jantan yang akan dipergunakan pada penelitian diadaptasi lingkungan selama 1 minggu dan diberikan pakan komersial (merk pellet 552) dan air minum ad libitum. Tikus dibagi menjadi dua kelompok masing-masing berjumlah 16 ekor. Kelompok I (perlakuan) yaitu 16 tikus pada daerah punggungnya dilukai dengan pisau scalpel sedalam $2 \mathrm{~mm}$ dan panjang $2 \mathrm{~cm}$ dan diberikan perlakuan bahan Extracellular matrix yang berasal dari vesica urinaria babi. Kelompok II (kontrol) yaitu 16 tikus diperlakukan sama dengan kelompok I dan tidak diberi perlakuan. Monitoring keamanan bahan matriks dilakukan pengamatan perkembangan kesembuhan luka pada 24 jam, hari ke 5, hari ke-10, dan hari ke-15 pasca operasi dengan pengamatan makros (kemerahan, bengkak, dan keropeng). Hasil pemeriksaan menunjukkan bahwa pemberian bahan Extracellular matrix mempercepat proses kesembuhan luka dibandingkan kelompok kontrol dengan tanda luka tertutup sempurna pada hari ke-15.
\end{abstract}

Kata kunci: Vesica Urinaria babi; matriks ekstraseluer; tikus putih jantan; luka

\begin{abstract}
Extracellular matrix (ECM) is currently one of the most commonly used scaffolds for tissue engineering procedures. Extracellular Matrix (ECM) can originate from the submucosa of the small intestine or vesica urinaria (urinary bladder) of a pig. The purpose of this study was to determine the suitability and safety level of using pig's vesica urinaria as an extracellular matrix to the process of healing open wounds in white rats and to find out the changes that occurred in the implant area after administration of urine vesica powder which was observed macroscopically. Thirty-two male white rats to be used in the study were adapted environmentally for 1 week and given commercial feed (pellet brand 552) and adlibitum drinking water. Rats were divided into two groups of 12 each. Group I (treatment) of 12 rats in the back area were injured with a scalpel blade $2 \mathrm{~mm}$ deep and $2 \mathrm{~cm}$ long and treated with extracellular matrix material derived from pig's vesica urinaria. Group II (control) ie 12 treated rats were the same as group I and were not treated. Monitoring the safety of the matrix material then observing the development of wound healing at 24 hours, day 5, day 10, and day 15 postoperatively by observing macros (redness, swelling, and scab). The results of the examination showed that the administration of extracellular matrix material accelerated the wound healing process compared to the control group with a perfect closed wound mark on the 15th day.
\end{abstract}

Keywords: Pig vesica urinaria; extracellular matrix; male white rat; wound. 


\section{PENDAHULUAN}

Luka adalah rusaknya kesatuan jaringan, dimana secara spesifik terdapat substansi jaringan yang rusak atau hilang. Luka secara umum terdiri dari luka yang disengaja dan luka yang tidak disengaja bertujuan sebagai terapi, misalkan pada prosedur operasi atau fungsi vena, sedangkan luka yang tidak disengaja terjadi akibat kecelakaan (Zulfa et al., 2008). Kesembuhan luka merupakan suatu proses yang kompleks dan saling berhubungan, dengan tujuan untuk mengembalikan fungsi jaringan yang rusak kembali seperti normal atau mendekati normal. Kesembuhan luka melibatkan proses seluler, fisiologis, biokemis dan molekuler yang menghasilkan pembentukan jaringan parut dan perbaikan dari jaringan ikat (Cockbill, 2002).

Reepitelisasi merupakan tahapan perbaikan luka yang meliputi mobilisasi, migrasi, mitosis, dan diferensiasi sel epitel. Penyembuhan luka sangat dipengaruhi oleh re-epitelisasi, karena semakin cepat proses reepitelisasi maka semakin cepat pula luka tertutup sehingga semakin cepat penyembuhan luka. Kecepatan dari penyembuhan luka dapat dipengaruhi dari zat- zat yang terdapat dalam obat yang diberikan, jika obat tersebut mempunyai kemampuan untuk meningkatkan penyembuhan dengan cara merangsang lebih cepat pertumbuhan sel-sel baru pada kulit (Prestyo et al., 2010).

Extracellular matrix (ECM) saat ini adalah salah satu yang paling umum digunakan sebagai perancah untuk prosedur rekayasa jaringan. Extracellular matrix (ECM) bisa berasal dari submukosa usus kecil atau vesica urinaria (kandung kemih) babi. Pengguna ECM ini telah menunjukkan hasil yang sangat baik dalam praklinis penelitian hewan dan uji klinis pada manusia. komponen ECM terdiri dari kolagen dan fibronegtin (Zhang, 2004). Menurut (Badylak, 2009) Extracellular matrix (ECM) adalah komponen ekstraseluler jaringan hewan yang umumnya memberikan dukungan struktural pada sel dan memiliki berbagai faktor pertumbuhan penting. Sumber biologis terdiri dari perancah ECM yang telah ditunjukkan untuk mempermudah renovasi konstruktif dari banyak jaringan yang berbeda dalam studi pada hewan dan manusia.

Berdasarkan hal tersebut, pada penelitian ini akan diteliti tentang efektivitas penggunaan vesica urinaria babi sebagai Extracellular matrix terhadap proses kesembuhan luka terbuka pada tikus putih jantan dengan melihat perubahan secara makroskopis.

\section{METODE PENELITIAN}

\section{Sampel Penelitian}

Tiga puluh ekor tikus putih jantan yang akan dipergunakan pada penelitian diadaptasikan terlebih dahulu selama 1 minggu. Tikus dibagi menjadi tiga kelompok masing-masing berjumlah 10 ekor. Kelompok I (kontrol negatif) yaitu tikus pada daerah punggungnya dilukai dengan pisau scalpel 10 sedalam $2 \mathrm{~mm}$ dan panjang $2 \mathrm{~cm}$ dan tidak diberikan perlakuan. Kelompok II (kontrol positif) yaitu tikus diberi perlukaan sama dengan kelompok I tapi diberikan perlakuan vaselin. Monitoring keamanan bahan matriks maka dilakukan pengamatan perkembangan kesembuhan luka pada 24 jam, hari ke 5, hari ke-10, dan hari ke-15 pasca operasi dengan pengamatan makros (bengkak, radang, keropeng).

\section{Rancangan Penelitian}

Penelitian ini menggunakan Rancangan Acak Lengkap (RAL) dengan pola kruskall wallis dengan melihat perubahan kondisi luka secara makroskopis.

\section{Pembuatan serbuk Extracellular matrix (ECM) dari vesica urinaria babi}

Pembuatan serbuk matrik ekstraseluler sama dengan metode (Freytes et al 2008). yang sedikit dimodifikasi meliputi proses: vesica urinaria babi dibersihkan dari sisa otot dan jaringan lemak menggunakan scalpel selanjutnya dicuci dengan $\mathrm{NaCl}$ fisiologis, kemudian vesica urinaria 
dipotong dengan ukuran $1 \mathrm{x} \quad 1 \mathrm{~cm}$ selanjutnya diblander menjadi bagian halus, selanjutnya direndam di dalam larutan yang meng and ung $0,1 \%$ asam perasetat, 4\% methanol, dan $95,9 \%$ aquabides selama 2 jam. Residu asam perasetat kemudian dihilangkan dengan dua kali pencucian $\mathrm{NaCl}$ fisiologis, diikuti dengan dua kali pencucian dengan aquabides masingmasing selama 15 menit, kemudian disimpan dalam tabung yang berisi alkohol $70 \%$ sampai diaplikasikan.

\section{Analisis data}

Hasil pemeriksaan hematologi makroskopis dianalisis secara statistic. Skoring dengan uji kruskall-wallis, bila berbeda nyata dilanjutkan dengan uji wilcoxon mann whitney untuk melihat perubahan kondisi luka seperti, keropeng, kemerahan, dan bengkak luka.

\section{HASIL DAN PEMBAHASAN}

Pemberian perlakukan bahan ekstraseluler matrik terhadap luka terbuka pada tikus putih menunjukan perubahan tehadap kesembuhan luka berupa, kemerahan, bengkak, dan keropeng. Hasil pengamatan makroskopik kesembuhan luka pada hari pertama, ke-5, ke-10, dan hari ke-15 dilihat dari tanda radang berupa kemerahan, kebengkakan dan pembentukan keropeng dapat dilihat pada Tabel 1.

Tabel 1. Kesembuhan luka

\begin{tabular}{|c|c|c|c|c|c|c|}
\hline \multirow[b]{2}{*}{ Hari } & \multicolumn{3}{|c|}{ Extracellular matrix (ECM) } & \multicolumn{3}{|c|}{ Kontrol } \\
\hline & $\begin{array}{c}\text { Kemerahan } \\
\text { (ekor) }\end{array}$ & $\begin{array}{c}\text { Bengkak } \\
\text { (ekor) }\end{array}$ & $\begin{array}{c}\text { Keropeng } \\
\text { (ekor) }\end{array}$ & $\begin{array}{c}\text { Kemerahan } \\
\text { (ekor) }\end{array}$ & $\begin{array}{c}\text { Bengkak } \\
\text { (ekor) }\end{array}$ & $\begin{array}{c}\text { Keropeng } \\
\text { (ekor) }\end{array}$ \\
\hline 1 & 16 & 16 & 0 & 16 & 16 & 0 \\
\hline 5 & 0 & 6 & 10 & 0 & 11 & 5 \\
\hline 10 & 0 & 0 & 16 & 0 & 9 & 7 \\
\hline 15 & 0 & 0 & 0 & 0 & 5 & 11 \\
\hline
\end{tabular}

Perubahan yang dapat diamati secara makroskopik pada tikus perlakuan I (kelompok tikus yang diberi perlakuan Extracellular matrix) adalah pada hari pertama kemerahan dan kebengkakan terjadi pada semua tikus tetapi pada hari tersebut keropeng belum terbentuk. Pada hari ke lima kemerahan sudah hilang pada semua ekor tikus, dan pada hari tersebut kebengkakkan sudah mulai menurun pada enam ekor tikus serta sudah terlihat adanya keropeng pada sepuluh ekor tikus. Pada hari kesepuluh, kemerahan dan kebengkakan sudah menghilang, tetapi jumlah tikus yang mengalami keropeng meningkat terlihat pada enambelas ekor tikus. Pada hari ke limabelas luka pada tikus putih yang diberikan Extracellular matrix vesica urinaria babi tertutup sempurna.

Perubahan yang dapat diamati secara makroskopik pada tikus kontrol II (kelompok tikus tanpa perlakuan) adalah pada hari pertama kemerahan dan kebengkakan terjadi pada semua tikus tetapi pada hari tersebut keropeng belum terbentuk. Pada hari ke lima kemerahan sudah hilang pada semua ekor tikus, dan pada hari tersebut kebengkakkan sudah mulai menurun pada sebelas ekor tikus serta sudah terlihat adanya keropeng pada lima ekor tikus. Pada hari kesepuluh, kemerahan sudah menghilang, tetapi kebengkakan masih terlihat pada tikus berjumlah Sembilan dan jumlah tikus yang mengalami keropeng meningkat terlihat pada tujuh ekor tikus. Pada hari kelimabelas masih terpantau.

Hasil pengamatan Extracellular matrix berdasarkan sistem skoring pada Kelompok Perlakuan dan Kelompok Kontrol berupa rerata (mean) dan signifikansi (Sig.) 0,05 tersaji pada Tabel 2. 
Tabel 2. Hasil rerata dan signifikansi kesembuhan perlakuan dan kontrol

\begin{tabular}{|c|c|c|c|c|c|}
\hline \multirow{2}{*}{ Perlakuan } & \multicolumn{4}{|c|}{ Waktu (hari) } & \multirow{2}{*}{ Rataan } \\
\hline & 1 & 5 & 10 & 15 & \\
\hline ECM & $3.00 \mathrm{~A}$ & $1.38 \mathrm{~A}$ & $0.69 \mathrm{~A}$ & $0.00 \mathrm{~A}$ & 1,26 \\
\hline Kontrol & $3.00 \mathrm{~A}$ & $1.69 \mathrm{~A}$ & $1.44 \mathrm{~B}$ & $0.69 \mathrm{~B}$ & 1,70 \\
\hline Rataan & 3.00 & 1,53 & 1,06 & 0,34 & \\
\hline Sig. $(0,05)$ & $\mathrm{a}$ & $\mathrm{b}$ & $\mathrm{c}$ & $\mathrm{d}$ & \\
\hline
\end{tabular}

Tabel 2 menunjukkan Mean (nilai rerata skoring) kesembuhan luka perlakuan (ECM) dan kontrol. Nilai rerata skoring Perlakuan (ECM) adalah 1,26 menunjukkan perubahan yang signifikan. Nilai rerata skoring Kontrol (tanpa perlakuan) 1,70 menunjukan perubahan signifikan $(\mathrm{P}<0,05)$.

Berdasarkan hasil pengamatan penggunaan extracellular matrix vesica urinaria babi sebagai peroses kesembuhan luka berbeda nyata dengan proses tanpa perlakuan. Pada proses kesembuhan luka dengan extracellular matrix, pada hari kesatu sampai hari kelimabelas terlihat perbedaan proses kesembuhan yang dominan cepat. Extracellular matrix sebagai media kesembuhan luka berpengaruh nyata terhadap kesembuhan luka. Dealey (1994) menjelaskan proses peradangan dapat diperpanjang akibat iritasi, infeksi, iritasi, bahan asing atau mekanik. Pada kontrol kemungkinan terjadinya infeksi sangat besar karena tidak dilakukan pengobatan yang dapat mencegah infeksi, hal tersebut menyebabkan proses peradangan diperpanjang.

Minggu pertama kesembuhan luka nyata berbeda dibandingkan dengan kontrol. Dalam waktu kurang lebih di hari kesepuluh luka yang diobati dengan Extracellular matrix tampak memperlihatkan gambaran sebagaimana jaringan dermis normal. Lapisan epidermis dan serabut kolagen telah ada dan membentuk anyaman yang menunjukkan fase kesembuhan telah mencapai tahapan maturasi (Dealey, 1994). Adanya kolagen pada minggu ketiga kesembuhan luka disebabkan telah terjadinya sintesis molekul kolagen dimulai dalam reticulum endoplasmic kasar fibroblast (Parker, 1991).

Penelitian tentang luka memiliki banyak tujuan, seperti memverifikasi keberadaan luka kronis, keberadaan luka yang terinfeksi, asal luka dan aspek lain yang mengklasifikasikan dan memberi ciri luka. Penelitian ini sangat penting karena memungkinkan para medis untuk mengontrol keadaan penyembuhan luka pasiennya dan dapat meningkatkan pengobatan luka dengan metode yang benar dan dalam waktu yang singkat (Pires dan Garcia, 2015).

Proses kesembuhan luka tanpa perlakuan sangat memerlukan waktu yang cukup lama untuk menutup sebuah luka insisi. Terlihat dari hasil diatas dari hari kesatu sampai hari kelimabelas belum terjadi kesembuhan luka yang sempurna. Proses penyembuhan luka sangat dipengaruhi oleh repitelisasi, karena semakin cepat proses reepitelisasi maka semakin cepat pula luka tertutup sehingga semakin cepat penyembuhan luka. Kecepatan dari penyembuhan luka dapat dipengaruhi dari zat- zat yang terdapat dalam obat yang diberikan, jika obat tersebut mempunyai kemampuan untuk meningkatkan penyembuhan dengan cara merangsang lebih cepat pertumbuhan selsel baru pada kulit (Prestyo et al, 2010).

Penyembuhan luka merupakan proses kompleks dan berkelanjutan sehingga jika terjadi gangguan pada satu fase akan mengganggu fase yang lainnya. Fase penyembuhan luka pasca insisi terdiri atas fase inflamasi, fase proliferasi, dan fase remodeling/maturasi. Fase inflamasi dimulai 24 jam pasca perlukaan yang ditandai dengan terbentuknya bekuan darah pada daerah insisi. Glikoprotein adhesif 
merupakan molekul yang strukturnya bermacam-macam, peran utamanya adalah melekatkan komponen matriks ekstraseluler satu sama lain dan melekatkan matriks ekstraseluler pada sel melalui integrin permukaan sel. Glikoprotein adhesif meliputi fibronektin (komponen utama matriks ekstraseluler interstisial) dan laminin (penyusun utama membran basalis). Protein matriks adhesif dapat secara langsung memerantarai perlekatan, penyebaran, dan migrasi sel. Karbohidrat menjadi komponen utama glikoprotein dalam penyembuhan luka (Titiek et.al., 2007).

Hambatan utama penyembuhan luka adalah adanya infeksi, peradangan, dan tidak seimbangnya kelembaban. Sehingga pada setiap fase penyembuhan luka memiliki karakteristik tersendiri dari segi warna dan tekstur luka. Area luka dapat mempunyai warna dan tekstur beragam yang berupa pengelupasan, jaringan granulasi merah dan jaringan nekrotik hitam (Prodan et al., 2006).

\section{SIMPULAN}

\section{Simpulan}

Berdasarkan pemaparan hasil di atas, Penggunaan bahan ekstraseluler matrik dari vesica urinaria babi sangat mempengaruhi kecepatan dalam proses kesembuhan luka insisi. Dilihat dari hari kelima Proses kesembuhan luka cepat terjadi dengan perlakuan extracellular matrix daripada tanpa perlakuan. Selang lima hari peroses kesembuhan luka dengan extracellular matrix vesica urinaria babi terilahat nyata luka sudah mulai mengecil sedangkan luka kontrol masih berukuran sama dengan hari kelima. Dihari kelimabelas perbedaan sangat terlihat nyata yang mana luka dengan perlakuan ekstraseluler matrik babi tertutup sempurna atau sembuh sempurna, sedangkan luka kontrol luka sudah mengecil tetapi masih terdapat keropeng dan belum menutup sempurna.

\section{Saran}

Penggunaan bahan extracellular matrix
dari vesica urinaria babi sangat

mempengaruhi kecepatan dalam proses kesembuhan luka insisi. Media ini bisa dikembangkan atau di lakukan kepada pasien yang mengalami luka robek atau insisi. Berdasarkan hasil penelitian, penggunaan extracellular matrix (ECM) vesica urinaria babi dapat mempercepat proses kesembuhan luka mulai dari hari ke10.

\section{DAFTAR PUSTAKA}

Badylak SF, Freytes DO, Gilbert TW. 2009. Extracellular matrix as a biological scaffold material: Structure and function. Acta Biomaterialia. 5: 113.

Titiek B, Waskito EB, Suwarno. 2007. Biochemical characterization of an antibacterial glycoprotein from Achatina fulica ferussac snail mucus local isolate and their implication on bacterial dental infection. Indonesia J. Biotechnol. 12(1): 944.

Cockbill S. 2002. Wounds the healing process. The Welsh School of Pharmacy. University College. Cardif.

Dealey C. 1994. The Care of Wound. Blackwell Science. USA.

Freytes OD, Jeffrey M, Sachin SV, Annie SL, Badylak SF. 2008. Preparation and rheological characterization of a gel form of the porcine urinary bladder matrix. Biomaterials 29: 1630-1637.

Freshney RI. 1986. Animal Cell Culture. Glasgow (UK): IRL Press.

Parker F. 1991. Structure and Function of The Skin. In Dermatology. M. Orkin, H.I. Maibach, dan M.V. Dahl. A Lange Medical Book.USA

Pavleti M.M. 1992. Veterynary Emergency and Critical Care Medicine. Editor Robert J. Murtaugh and Paul M. Kaplan. Mosby Year Book. Toronto. New York

Peterson AS. 2010. The Golden period for wound repair. J. Lancaster General Hospital. 5(4): 134-135.

Pires IM, Garcia N, 2015. Wound area assessment using mobile application. 
Int. Conference on Biomedical Electronics and Devices. Pp. 271-282.

Prestyo BF, Wientarsih I, Priosoeryanto

BP. 2010. Aktivitas sediaan gel ekstrak batang pohon pisang ambon dalam proses penyembuhan luka pada mencit. J. Vet. 11(2): 70-73.

Prodan A, Rusu M, Campean R, Prodan R. 2006. A java framework for analyzing and processing wound images for medical education. Proceedings $20^{\text {th }}$ European Conference on Modelling and Simulation (ECMS).
Zhang Y, Kropp BP, Lin HK, Cowan R, Cheng EY. 2004. Bladder regeneration with cell-seeded small intestinal submucosa. Tissue Eng. 10: 181-187.

Zulfa, Murachman E, Gayatri D. 2008. Perbandingan Penyembuhan luka terbuka menggunakan balutan Madu atau balutan normal salin-povidone iodine. J Keperawatan Indo. 12(1): 3439. 